\title{
Maintenance of oral hygiene of patients admitted to intensive care units in hospitals.
}

Antônio Silva Carlos Duarte (1)

\section{ARTIGO ORIGINAL}

\section{Abstract}

Objective: The prevention of diseases and humanization of inpatients occurs with a greater integration of dentistry and medicine, aiming at a global treatment of patients. Therefore, this study aims to show the importance of the dentist, general practitioner, within an intensive care unit. Materials and methods: The methodology used was a questionnaire, in which some questions were asked to six doctors and six nurses responsible for the Intensive Care Units, of the four main hospitals in Passo Fundo / RS, seeking to evaluate the presence of the DC in the ICUs, the care performed, associated comorbidities and the degree of acceptance of dental professionals in these units. Result: The presence of a dental surgeon is not prioritized in two of the evaluated hospitals, in any of its three intensive care units, contrary to the legislation in force on April 18, 2013. Conclusion: It was concluded that it is of the utmost importance for the $\mathrm{HC}$ in the hospital network, aiming at an improvement in the clinical condition of inpatients, reduction of infections, reduction of medication and number of beds, attenuating the index of oral pathogens due to poor hygiene, reducing hospital costs and showing that it is necessary to insert the DC in the ICU multiprofessional team.

Keyword: Intensive care unit, Hospital, Oral health. 


\section{Manutenção da higiene oral de pacientes internados em unidades de terapia intensiva de hospitais.}

\section{Resumo}

Objetivo: A prevenção de doenças e humanização dos pacientes internados se dá com uma maior integração da odontologia e medicina, visando um tratamento global dos pacientes. Portanto, o presente trabalho tem como objetivo mostrar a importância do cirurgião-dentista, clínico geral, dentro de uma unidade de terapia intensiva. Materiais e métodos: A metodologia utilizada foi um questionário, no qual foram feitas algumas perguntas para seis médicos e seis enfermeiros responsáveis pelas Unidades de Terapia Intensiva, dos quatro principais hospitais de Passo Fundo/RS, buscando avaliar a presença do CD nas UTIs, os cuidados realizados, as comorbidades associadas e o grau de aceitação dos profissionais da odontologia nestas unidades. Resultado: A presença de cirurgião-dentista não é priorizada em dois dos hospitais avaliados, em nenhuma de suas três unidades de terapia intensiva, contrariando a legislação vigente de 18 de Abril de 2013. Conclusão: Concluiu-se que é de suma importância do CD na rede hospitalar, visando uma melhora no quadro clínico dos pacientes internados, diminuição de infecções, redução de medicação e quantidade de leitos, atenuando o índice de patógenos bucais devido à má higiene, diminuindo os custos hospitalares e mostrando que se faz necessário a inserção do CD, na equipe multiprofissional das UTIs.

Palavras-chave: Unidade de terapia intensiva, Hospital, Saúde bucal.

Instituição afiliada: 1- Cirurgião Buco Maxilo Facial do Hospital de Urgência e Emergência de Santana, Santana, Amapá, Brasil.

Dados da publicação: Artigo recebido em 10 de Março, revisado em 15 de Março, aceito para publicação em 20 de Março e publicado em 28 de Março.

DOI: https://doi.org/10.36557/2674-8169.2021v3n2p02-09

Antônio Silva Carlos Duarte tonhobuco@gmail.com

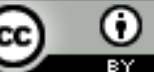

This work is licensed under a Creative Commons Attribution 4.0 International

License. 


\section{INTRODUÇÃO}

The incorporation of the dental surgeon to the hospital team contributes to the patient's well-being and dignity, preventing infections, reducing the length of hospital stay and the use of medications. However, its inclusion in multidisciplinary hospital teams, especially within Intensive Care Units (ICUs), is not yet a reality, being neglected by most Brazilian hospitals (1).

The ICUs were created with the objective of assisting patients in critical condition who need assistance and permanent care from the multidisciplinary team, as well as a greater concentration of material resources.

Studies indicate that ICU patients have poor oral hygiene, with a significantly higher amount of biofilm than individuals who live integrated into society. It is also possible to observe in these patients, greater colonization of oral biofilm by respiratory pathogens. Since, the quantity and complexity of the oral biofilm increases with the length of hospital stay.

These results lead such studies to suggest that colonization of oral biofilm by pathogens, especially respiratory ones, may be a specific source of nosocomial infection that is important in the ICU (2).

When referring to hospital dentistry, it is immediately associated with curativerehabilitative treatment carried out exclusively by the dentist, however, its activities also involve educational-preventive actions in hospital units. In view of these precepts, the dentist can and must always work integrated with other professionals, such as nursing staff (auxiliary and nursing technician and nurse), dental hygiene technicians (THD) and dental office assistant $(A C D)$ trained and oriented on oral hygiene methods suitable for patients (3).

The objective of this research is to verify the importance of maintaining oral hygiene of patients admitted to an intensive care unit with a focus on four intensive care units in Passo Fundo / RS and to show, through a questionnaire, which dental care is provided to patients admitted to intensive care units. intensive care.

\section{MATERIAS E MÉTODOS}

This qualitative research was carried out with doctors and nurses who are heads of intensive care units in Passo Fundo / RS, through a semi-structured questionnaire with open questions. This research was approved by the IMED Research Ethics Committee, under number 272,087 . The data were analyzed descriptively from each answer given by the doctors and nurses interviewed in the four hospitals in Passo Fundo / RS with ICUs (Hospital São Vicente de Paulo, Institute of Orthopedics and Traumatology - IOT, Hospital Pronto Clínica and Hospital da Cidade). The sample consisted of 6 nurses and 6 doctors, 
having in each of the hospitals only one ICU, only the São Vicente de Paulo Hospital, the interview was carried out in each of its three ICUs, Central, Cardiac and Pediatric. The sampling was non-probabilistic, carried out for convenience in the shift in which the interviews were conducted.

The questions addressed were as follows: Question 1: Do you have a dental surgeon who provides care to patients admitted to the Intensive Care Unit? Question 2: What dental care is performed on patients admitted to the Intensive Care Unit? Question 3: Which comorbidities do you think are associated with oral diseases (periodontopathies and caries disease)? Question 4: What degree of acceptance and need for dental professionals in Intensive Care Units?

\section{RESULTADOS E DISCUSSÃO}

Concomitantly, by the methodology adopted, the results of the work and so discussed as the review shows that the presence of a Dental Surgeon is not prioritized at Hospital São Vicente de Paulo and Hospital Pronto Clínica, contrary to the legislation in force on April 18, 2013 which proclaims the mandatory presence of this professional in a hospital environment, unlike the other two hospitals Hospital da Cidade and IOT, which not only recognize the need for this professional in the permanent care staff of critical patients in the ICU, but also in the IOT.

As for the care performed in the ICU, these focus not only on the curativerehabilitation aspect, but, above all, and more closely, in preventive therapies, as emphasized Lima (3), associated with dental hygiene technicians and trained nursing, which is implicit in the answers, but with a clear lack of protocol and uniformity even in the same institution, with oral hygiene with brushing, no routine hygiene or application of $0.12 \%$ chlorhexedine in HSVP, or hygiene and evaluation, $0.12 \%$ chlorhexedine 4 times a day, morning visits by the DC and new patients admitted to the unit new exams, at the IOT. In HC oral hygiene and chlorhexedine $0.12 \%$ and in Pronto Clínica in patients with Cepacol mechanical breathing three times a day with forceps and gauze, in conscious selfhygiene, which, like Meira (1), leads us to question the quality of hygiene and hospital care provided here, as well as in the country, due to the lack of supervision or lack of uniformity, as emphasized by Godoi (4) and Silveira et al. (5), the unanimous interaction and training of the assistant team is essential, especially in hospitals where working conditions

dentistry and the needs of inpatients differ significantly in relation to the offices and their routines.

As for the associated comorbidities, the relationship between endocarditis, pneumonia, gastroesophageal reflux and oral sepsis was unanimous, as well as caries, gingivitis, root debris, oral candida, absence

dental, aesthetics and pain, conditions well defined in the literature, according to Rabelo et al. (6), Kahn et al. (7), Santos et al. (8). Caries, mucositis, periodontitis and oral diseases are aggravated or precipitated by diseases such as diabetes, cancer, hypophosphatasias, low immunity and lead to deterioration of oral health with functional loss and complications according to Camargo (9). 
The acceptance and need for professional dentistry in the ICU is well established and without restrictions although it must be adequate to the demand and the particular needs, especially in pediatric units. The professionals involved, doctors and nurses understand the importance of $C D$ in this routine, but they still seem to have some difficulty in locating it. The control of various oral conditions can be performed by trained personnel according to Martins (10).

The role of the nursing team is of fundamental importance in patient care, according to a study by Orlandini

and Lazarri (11), who evaluated the knowledge of nursing professionals who consider oral hygiene important in critically ill patients. Although the responsibility for

the need for oral care falls on the team leader nurses themselves. In our study, it was possible to notice that the understanding of hygiene maintenance and its importance is more widespread by nurses than by doctors responsible for ICUs in the city of Passo Fundo / RS.

Barros et al. (12), carried out a study showing the importance of CD in the Unified Health System, which states the responsible physician

by the ICU of Hospital Pronto Clínica, saying that the dental surgeon is only necessary in the clinical staff of Hospitals with care focused on SUS, but our study shows that this statement is erroneous, as the implementation of the Dental Surgeon in maintaining oral hygiene can avoid numerous complications.

Greater integration of dentistry and medicine is necessary, aiming at a global treatment of patients, disease prevention and greater humanization of patients admitted to the ICU, according to Morais et al. (2), this is in agreement with our study, which found a lack of interdisciplinarity and transdisciplinarity among the professionals involved, dental surgeons, dental hygiene technicians, nursing staff and, above all, doctors.

The limitations found in this work were the interviewees' difficulty in answering the questions, having to appear several times in hospitals to get an answer. The little understanding of the professionals who answered the questionnaire which also generated unsatisfactory and incomplete answers, due to the little knowledge of the importance of the Dentistry professional integrated to the hospital environment, mainly in the ICU, differentiating him from the Oral and Maxillofacial Surgeon, who in turn has already has a recognition before the hospital team.

\section{CONCLUSÃO}

The study showed the importance of the dentist, a general practitioner in a hospital environment, attenuating the rate of oral pathogens due to poor hygiene. It is necessary to insert the DC in the hospital environment (in the ICU) and a greater interdisciplinarity among health professionals, aiming at the prevention and maintenance of oral hygiene. 


\section{THE AUTHORS DECLARE NO CONFLICTS OF INTEREST.}

\section{REFERÊNCIAS}

1. Meira RCS, Oliveira CAS, Ramos IJM. A importância da participação do cirurgiãodentista na equipe multiprofissional hospitalar. Trabalho vencedor na 9o edição do prêmio Sinog de Odontologia 2010. Disponível em: http://www.sinog. com.br/premio/vencedores/2010/EST2010.pdf

2. Morais TMN, Avi AL, Souza PHR, Knobel E, Camargo LFA. A Importâcia da Atuação Odontológica em Pacientes Internados em Unidade de Terapia Intensiva. Revista Brasileira de Terapia Intensiva. 2006; 18(4):412-17.

3. Lima DC, Saliba NA, Garbin AJI, Fernandes LA, Garbin CAS. de et al. A importância da saúde bucal na ótica de pacientes hospitalizados. Ciênc. saúde coletiva. 2011; 16 (1): 1173-80.

4. Godoi APT, Francesco AR, Duarte A, Kemp APT, Silva-Lovato CH. Odontologia Hospitalar no Brasil- uma visão geral. Revista de Odontologia da UNESP. 2009; 38 (2): 105-9.

5. Silveira IR, Maia FOM, Gnatta JR, Lacerda RA. Higiene bucal: prática relevante na prevenção de pneumonia hospitalar em pacientes em estado crítico. Acta Paul Enferm, 2010; 23 (5): 697-700.

6. Rabelo DG, Queiroz Cl, Santos PSS. Atendimento odontológico ao paciente em Unidade de Terapia Intensiva. Arq. Med. Hop. Fac. Cienc. Med. Santa Casa São Paulo. 2010; 55 (2): 67-70.

7. Kahn S, Mangialardo ES, Garcia CH, Namen FM, Galan J, Machado WAS. Controle de infecção oral em pacientes internados: uma abordagem direcinada aos médicos intensivistas e cardiologistas. Rev. Ciência e Saúde Coletiva. 2010; 15 (1): 1819-26.

8. Santos PSS, Mello WR, Wakim RCS, Paschoal MAG. Uso de solução bucal com sistema enzimático em pacientes totalmente dependentes de cuidados em unidade de terapia intensiva. Rev. Bras. Ter. Intensiva. 2008; 20 (2): 154-9.

9. Camargo EC. Odontologia hospitalar é mais do que cirurgia bucomaxilofacial. Jornal do site-odonto. 2005; 8 (98): Disponível em: http://www. jornaldosite.com.br/arquivo/anteriores/elainecamargo/artelainecamargo98.htm.

Acesso em: 30 de maio de 2013. 
10. Martins MTF. Odontologia Hospitalar Intensiva: Interdisciplinariedade e desafios. Disponível em: < http:/www.abraoh.com.br>. Acesso em: 03 out 2013.

11. Orlandini, GM, Lazzari, CM. Conhecimento da equipe de enfermagem sobre higiene oral em pacientes criticamente enfermos. Rev. Gaúcha Enferm. 2012; 33 (3): 34-41.

12. Barros CS, Pimentel GC, Bezerra MMM, Aguiar Filho NB, Santos ES. Atuação odontológica na Unidade de Terapia Intensiva(UTI) do Hospital Geral de Fortaleza (HGF). Perionews. 2011; 5 (2): 271-5.

13- ORLANDINI, Thaís Rita Mottes; BASUALDO, Alexandre; OLIVEIRA, Karen Correa. Manutenção da higiene oral de pacientes internados em unidades de terapia intensiva de hospitais. Journal of Oral Investigations, v. 2, n. 2, p. 4-8, 2015.

\section{DECLARAÇÃO CCBY}

This article is a literal copy of the original article "ORLANDINI, Thaís Rita Mottes; BASUALDO, Alexandre; OLIVEIRA, Karen Correa. Manutenção da higiene oral de pacientes internados em unidades de terapia intensiva de hospitais. Journal of Oral Investigations, v. 2, n. 2, p. 4-8, 2015. ". This copy is adapted for English and does not contain the original author's address, unless the authorization provided by CCBY.

This is the license link for this article https://creativecommons.org/licenses/by/4.0/deed.pt BR

This is the link to the original article
https://seer.imed.edu.br/index.php/JOl/article/view/824/587 